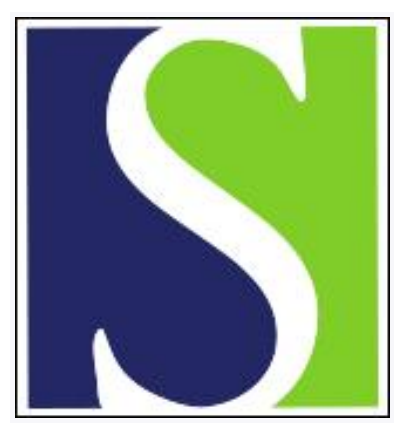

Scand J Work Environ Health 1985;11(1):1-6

https://doi.org/10.5271/sjweh.2260

Issue date: Feb 1985

Current trends in the biological monitoring of exposure to carcinogens.

by Vainio $\mathrm{H}$

This article in PubMed: www.ncbi.nlm.nih.gov/pubmed/3887561

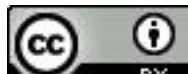




\title{
Current trends in the biological monitoring of exposure to carcinogens
}

\author{
by Harri Vainio, $M D^{1}$
}

VAINIO H. Current trends in the biological monitoring of exposure to carcinogens. Scand J Work Environ Health 11 (1985) 1-6. The biological monitoring of exposure to carcinogens and mutagens has gained a lot of research interest recently. Biological monitoring data, in conjunction with environmental monitoring data, will provide information for the needed exposure assessment for directing preventive actions. For the reviewed carcinogens aromatic amines, benzene, ethylene oxide, aflatoxins, $N$-nitroso compounds, polynuclear aromatic hydrocarbons, and alkylating anticancer drugs, there are methods which are already routine in practice, whereas some promising methods are still used only for research purposes.

Key terms: chromosome aberrations, DNA (deoxyribonucleic acid) adducts, micronuclei, mutage:aicity in urine, mutagens, protein adducts, SCE, sister chromatid exchange.

Biological monitoring can be used for improving the evaluation of the dose received from environmental or occupational exposure and for the early detection of reversible biological effects. The aim of monitoring exposure to carcinogens and mutagens, in particular, is to prevent irreversible toxic effects, since such effects are assumed (although they have not been proved) to be early steps in chemical carcinogenesis. Biological monitoring is not, however, a substitute for environmental monitoring; instead it is a complementary activity, especially in the case of carcinogens, for which the latency between exposure and effects may be long - often decades (3).

In the following review I shall give some examples of the possibilities for monitoring exposure to carcinogens. Figure 1 shows the relationships between external exposure, several measures of dose, and responses, with examples of tests that can be used in each category. Two notes of caution should be introduced. First, although methods have developed rapidly during the last few years, they are still very much at the research stage. Second, when the results of the biological monitoring of occupational exposure are being interpreted, possible modifying and/or confounding effects of personal habits, such as smoking, must be taken into account, especially in the case of nonspecific methods, such as measurements of urinary mutagenicity and of sister chromatid exchange (SCE) in lymphocytes.

\footnotetext{
${ }^{1}$ Division of Environmental Carcinogenesis, International Agency for Research on Cancer, 150 cours Albert Thomas, F-69372 France.
}

Reprint requests to: Prof $\mathrm{H}$ Vainio, Institute of Occupational Health, Haartmaninkatu 1, SF-00290 Helsinki, Finland.

\section{Aromatic amines}

Primary aromatic amines such as 2-naphthylamine and 4-aminobiphenyl have been identified epidemiologically as human bladder carcinogens; they also produce cancer in the bladder and other organs of dogs, monkeys, and rodents $(17,18)$. Biological monitoring of exposure to aromatic amines is of particular interest, for two reasons. First, some of these compounds are well absorbed via the skin, so that environmental monitoring alone is insufficient to estimate dose. Second, since genetic factors are highly important in the metabolism of aromatic amines, susceptible individuals can be identified only through biological monitoring.

Nonspecific methods, such as the measurement of total urinary amino compounds, blood methemoglobin levels, and mutagenic activity in urine, can be applied in situations where exposure is to a number of different aromatic amines with differing toxicologic properties (25). However, specific methods, such as the measurement of blood protein adducts, are preferable in situations where environmental measurements and occupational hygiene data indicate that exposure may have been to a single aromatic amine.

It has been suggested (26) that the target organ affected by an aromatic amine is, at least partially, dependent on the rate of metabolic activation. In the dog, which has low acetyl transferase activity with regard to aromatic amines, 4-aminobiphenyl is an effective bladder carcinogen. In humans, aromatic amine acetyl transferase shows genetic polymorphism, so that populations display two distinct phenotypes - the "slow acetylator" or the "fast acetylator" (10). Epidemiologic studies have shown an association between low acetyl transferase activity and the risk of bladder cancer $(7,26)$. 


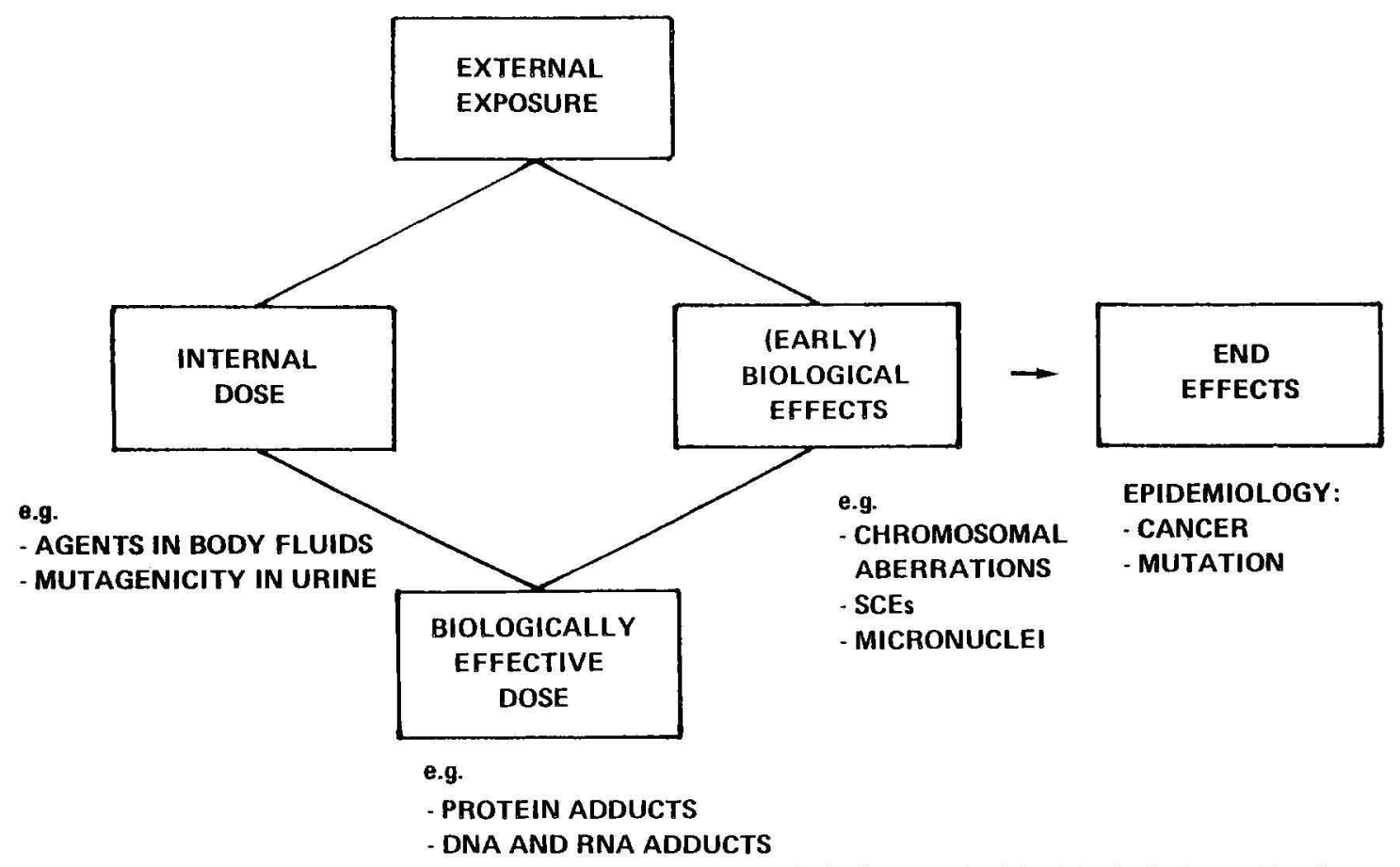

Figure 1. Association between external exposure, internal dose, biological effects, and epidemiologically detectable effects. (SCEs = sister chromatid exchanges, DNA = deoxyribonucleic acid, RNA = ribonucleic acid)

Skipper et al (39) have demonstrated that 4-aminobiphenyl administered to experimental animals results in the formation of two distinct types of covalent adduct between the carcinogen and both serum albumin and hemoglobin. In albumin the site of attack is the single tryptophan residue, and the adduct is formed from acetylated 4-aminobiphenyl. In hemoglobin the adduct is assumed to be a product of the direct action of a mixed-function oxidase on the amine. The simultaneous measurement of these two adducts thus offers an opportunity to investigate the role of both 4-aminobiphenyl and acetylator status in bladder carcinogenesis: albumin adducts are used to measure the fraction of 4-aminobiphenyl that undergoes $N$-acetylation, while hemoglobin adducts measure the fraction that is not acetylated.

The method developed by Skipper et al (38) is capable of detecting less than $100 \mathrm{pg}$ of adduct in $10 \mathrm{ml}$ of blood. A monoclonal antibody has been produced to facilitate the quantitation of 4-aminobiphenyl-serum albumin adducts (39).

\section{Benzene}

Benzene is a leukemogen in humans (19) and a carcinogen at many sites in animals (27). It is unquestionably a myelotoxic agent, producing pancytopenia and eventual aplastic anemia in all animal species studied (19).

The biological monitoring of exposure to benzene was reviewed recently (3). The main monitoring methods used are measurement of the major urinary metabolite, phenol (free or conjugated), and measurement of benzene concentrations in exhaled air and blood. The presence of phenol in urine is a nonspecific indicator and is perhaps not sensitive enough to detect low levels of benzene exposure. The benzene concentration measured in expired air during exposure reflects the exposure only at the time of sampling; the benzene content of breath the morning after exposure best reflects the integrated exposure during the preceding day (25). The determination of benzene in blood is specific and thus is the method of choice for low levels of exposure to benzene. Since bone marrow retains 20 times as much benzene as the blood at equilibrium, the finding of even low levels of benzene in blood may be of toxicologic significance (4).

Benzene has been shown to be a moderately strong clastogen, as determined by cytogenetic analysis of mouse bone marrow (29). Increases in the number of chromosome-type aberrations have been noted in persons exposed occupationally to high concentrations of benzene (12). This compound appears to induce chromosome damage only in cells that replicate their deoxyribonucleic acid (DNA), a phenomenon which would preclude a direct effect on peripheral lymphocytes. Cytogenetic data on peripheral lymphocytes may therefore grossly underestimate the actual effect produced in bone marrow. The small effect produced in stem cells by such S-dependent chemicals may be completely undetectable in the cytogenetic analysis of peripheral lymphocytes (5).

Thus great caution should be exercised when the results of cytogenetic surveys of benzene-exposed 
persons are interpreted, especially when no obvious effect is evident. When an effect is found, however, it is reasonable to suggest that the increase in chromosome aberrations should be regarded as an indicator of genotoxic hazard. The induction of chromosome aberrations cannot be used, at present, for risk assessment at the individual level but only at a group level (12).

\section{Ethylene oxide}

Ethylene oxide is widely used as a chemical sterilant and as a fumigant in food. It is mutagenic in bacteria, plants, fungi, and insects (22). Ethylene oxide administered to rats by inhalation increased the incidence of mononuclear-cell leukemia (40). Epidemiologic studies of two occupationally exposed populations in Sweden are suggestive of an association between ethylene oxide and leukemia (15). [For further discussion, see the report of the International Agency for Research on Cancer (22).]

Considerable attention has been paid to the biological monitoring of exposure to ethylene oxide. Ehrenberg et al (9) have developed sensitive chemical methods for detecting the alkylation of hemoglobin after exposure to electrophilic compounds such as ethylene oxide. The measurement of hydroxyethyl groups in amino acid residues in hemoglobin appears to provide a good estimate of the dose of ethylene oxide delivered to tissues and to tissue DNA, in both experimental animals and humans $(36,45)$.

Exposure of workers to ethylene oxide in the workplace has been associated with increases in the frequencies of sister chromatid exchanges in their peripheral blood lymphocytes (22). A recent report from three sterilization plants in the United States also suggests a dose-dependent increase in the incidence of sister chromatid exchange in workers' lymphocytes (42). Exposure to ethylene oxide has also been found to lead to structural chromosome aberrations in peripheral lymphocytes (14) and to an increase in micronucleated bone marrow cells (14).

Although it is nonspecific, determining the frequency of sister chromatid exchange in blood lymphocytes from ethylene oxide-exposed workers thus appears to be a sensitive and promising tool for detecting biological effects, although possible confounding factors should be kept in mind when the results of such occupational exposure monitoring methods are interpreted.

\section{Aflatoxins}

Epidemiologic studies have strongly implicated hepatitis $B$ virus infection as a major risk factor in the induction of primary liver cancer (28). However, a number of other studies indicate a multifactorial origin for this cancer, and additional risk factors, such as aflatoxins, must still be considered to be of etiologic importance, especially since aflatoxins have been detected in many commonly consumed foodstuffs. Aflatoxin $B_{1}$ is a potent carcinogen in rats, but it may also induce hepatic injury and hepatoma in a wide species range, including nonhuman primates (18). Its wide spectrum of animal hepatocarcinogenicity indicates that humans might not be an exception.

The recent development of immunologic techniques that involve the use of antibodies that are highly sensitive and specific against certain carcinogens, including aflatoxin $B_{1}$, opens the possibility of determining individual exposures in a relatively large human population (21).

The $\mathrm{P}^{32}$-postlabeling technique (36) is nonspecific, but the reaction between carcinogens and DNA can be detected at levels of as little as 1 base $/ 10^{7}-10^{8}$ nucleotides. However, while the procedure appears to be promising, it is still in the developmental stage, and only a few studies have been carried out with aflatoxins.

Measurements of aflatoxin $B_{1}$ and its metabolites in urine reflect recent exposure to aflatoxins. Preliminary studies from Kenya have been reporting the use of a fluorescence assay for the detection of aflatoxin $\mathrm{B}_{1}$-guanine in the urine of subjects living in a region with high exposure to aflatoxins and with an elevated incidence of liver cancer (1). The adaptability of this method to wide use in biological monitoring warrants further investigation.

\section{$\boldsymbol{N}$-nitroso compounds}

$N$-nitroso compounds have been shown to produce tumors in 40 animal species to date and in most organs of the body. The question of whether humans are resistant or not has not yet been convincingly answered, but there is no reason to believe that they are different from other species in this respect.

Humans may be exposed to carcinogenic $N$-nitroso compounds as a result of the ingestion or inhalation of preformed compounds in the environment or of the nitrosation of amino precursors in the body. Recently, a method was developed for estimating potential in-vivo nitrosation in humans (32). It is based on the finding that certain $N$-nitrosamino acids, such as $N$-nitrosoproline, are excreted predominantly in the urine after precursors (proline and nitrate or nitrite) are ingested. This finding makes it possible to study the kinetics of and the factors affecting nitrosation in vivo in humans. The $N$-nitrosoproline test can also be used to assess an individual's capability to produce endogenous carcinogens. For instance it has been found that endogenous nitrosation is increased in tobacco smokers (13). Furthermore, this test can be used in clinical and field studies to evaluate the role of endogenous $N$-nitroso compounds in the etiology of cancers at specific sites, such as the stomach and esophagus (2). 


\section{Polynuclear aromatic hydrocarbons}

Exposure to polynuclear aromatic hydrocarbons occurs principally through the direct inhalation of tobacco smoke and polluted air and, possibly, through the ingestion of contaminated and processed food and water and dermal contact with soot, tar, and oil (20). Polynuclear aromatic hydrocarbons have long been considered potential human health hazards, since many members of this class are carcinogenic in animals.

The urine of workers exposed occupationally to these hydrocarbons showed mutagenic activity, which could be correlated with their concentration in urine (23).

In preliminary studies, benzo[a]pyrene-DNA adducts were detected in tissues and in peripheral blood samples from people exposed to benzo[ $a]$ pyrene, through either smoking or occupational exposure. Wide interindividual variation in the amounts of adducts formed has been found, and this variation may reflect differences in exposure to benzo[a]pyrene, in its metabolic activation or inactivation, or in DNA repair rates $(33,37)$.

\section{Anticancer drugs}

Many anticancer drugs are both carcinogenic and mutagenic (16). Patients treated with these drugs represent an ideal population for dosimetric and epidemiologic studies of genetic end points, which could be used in "parallelogram-type methods" (6) to correlate findings from experimental animals with those from humans.

The urine of patients treated with alkylated cytostatic drugs is mutagenic to bacteria (11), and such treatment increases the frequency of sister chromatid exchange in their peripheral blood lymphocytes (24). Patients treated with certain anticancer drugs have also been shown to have an increased risk for second primary tumors (8).

The first indication of a possible risk of hospital personnel exposed to anticancer drugs came from a study by Falck et al (11), in which an association was made between increased mutagenicity in urine and contact with cytostatic drugs. Urinary mutagenicity measured by the bacterial fluctuation assay was significantly higher among oncology nurses than among office clerks. Subsequently, however, conflicting results were reported on the association between the occupational handling of cytostatic drugs and mutagenicity in urine (43).

Many anticancer drugs, such as alkylating cytostatic drugs and some antibiotic-type chemotherapeutic agents, have been shown to induce both chromosome aberrations and sister chromosome exchange in human and rodent cells in vitro and in cancer patients in vivo (43). A few cytogenetic studies have also shown effects of low-level exposures at the group level. Thus a group of oncology nurses showed a significantly increased frequency of sister chromosome exchange in their lymphocytes as compared with office workers $(31,41)$. Waksvik et al (44) also reported an increase in the number of sister chromosome ex-

Table 1. Correlations between experimental and epidemiologic findings - Some examples. ${ }^{a}$ (PAHs $=$ polycyclic aromatic hydrocarbons, DNA = deoxyribonucleic acid)

\begin{tabular}{|c|c|c|c|c|c|c|c|c|}
\hline \multirow[b]{2}{*}{ End point } & \multicolumn{8}{|c|}{ Exposure } \\
\hline & $\begin{array}{l}\text { Aromatic } \\
\text { amines }\end{array}$ & Benzene & $\begin{array}{l}\text { Ethylene } \\
\text { oxide }\end{array}$ & Aflatoxins & $\begin{array}{l}N \text {-nitroso } \\
\text { compounds }\end{array}$ & $\begin{array}{l}\text { Iron \& steel } \\
\text { foundries } \\
\text { (PAHs) }\end{array}$ & $\begin{array}{l}\text { Alkylating } \\
\text { anticancer } \\
\text { drugs }\end{array}$ & $\begin{array}{l}\text { Cigarette } \\
\text { smoke }\end{array}$ \\
\hline \multicolumn{9}{|c|}{ In-vitro tests for genetic activity } \\
\hline $\begin{array}{l}\text { DNA damage } \\
\text { Mutation } \\
\text { Chromosome effects }\end{array}$ & $\begin{array}{l}+ \\
+ \\
+\end{array}$ & $\overline{\bar{t}}$ & $\begin{array}{l}+ \\
+ \\
+\end{array}$ & $\begin{array}{l}+ \\
+ \\
+\end{array}$ & $\begin{array}{l}+ \\
+ \\
+\end{array}$ & $\begin{array}{l}\because \\
+ \\
+\end{array}$ & $\begin{array}{l}+ \\
+ \\
+\end{array}$ & $\begin{array}{l}+ \\
+ \\
+\end{array}$ \\
\hline Bioassays & & & & & & & & \\
\hline Carcinogenicity & + & + & + & + & + & $(+)$ & + & + \\
\hline \multicolumn{9}{|l|}{ Studies in humans } \\
\hline $\begin{array}{l}\text { Presence of agent(s) in } \\
\text { body fluids } \\
\text { Mutagenicity in body }\end{array}$ & + & + & + & + & + & + & + & + \\
\hline $\begin{array}{l}\text { fluids } \\
\text { Covalent adducts }\end{array}$ & $\begin{array}{l}+ \\
+\end{array}$ & $\begin{array}{l}\cdots \\
\cdots\end{array}$ & $\ddot{+}$ & $\begin{array}{l}\cdots \\
+\end{array}$ & $\begin{array}{l}+ \\
+\end{array}$ & $\stackrel{+}{(+)}$ & $\begin{array}{l}+ \\
+\end{array}$ & $\begin{array}{l}+ \\
+\end{array}$ \\
\hline $\begin{array}{l}\text { Chromosome aberrations } \\
\text { Sister chromatid }\end{array}$ & . & + & + & $\cdots$ & $\cdots$ & $(+)$ & + & + \\
\hline $\begin{array}{l}\text { exchanges } \\
\text { Micronuclei }\end{array}$ & $\begin{array}{l}\cdots \\
\cdots\end{array}$ & $\overline{-}$ & $\begin{array}{l}+ \\
+\end{array}$ & $\begin{array}{l}\cdots \\
\cdots\end{array}$ & $\begin{array}{l}\cdots \\
\cdots\end{array}$ & $\begin{array}{l}(+) \\
\cdots\end{array}$ & + & $\begin{array}{l}+ \\
+\end{array}$ \\
\hline \multicolumn{9}{|l|}{ Epidemiologic studies } \\
\hline Cancer & + & + & $(+)$ & $(+)$ & $(+)$ & $(+)$ & + & + \\
\hline
\end{tabular}

$a^{a}=$ positive data, $(+)=$ suggestive data, $-=$ negative data, $\cdots=$ no data 
changes and of chromosome gaps among nurses handling cytostatic drugs, and Nikula et al (30) found a higher frequency of chromosomally aberrant lymphocytes in oncology nurses than in laboratory workers and hospital clerks (30).

These limited results suggest that personnel handling anticancer drugs may be exposed through inhalation and skin contact. They also suggest that nonspecific methods, such as measuring mutagenicity in urine and clastogenic changes in lymphocytes, could be used for monitoring such exposure biologically.

\section{Biological monitoring as a bridge between laboratory and epidemiologic studies}

The identification and assessment of risk can benefit from the merging of experimental studies and epidemiologic investigations. Although epidemiologic studies provide unique information about the responses of humans who have been exposed to suspect agents, they can detect only relatively large increases in relative risk, and usually only retrospectively. In addition, although they may provide evidence for an association they often cannot provide direct proof of a cause and effect relationship. Results of exposure monitoring, dubbed "molecular cancer epidemiology" by Perera \& Weinstein (34), must be combined with epidemiologic methods in order to identify end effects other than cancer as early warning signs. Table 1 illustrates the need to integrate the disciplines of in vitro toxicology, experimental carcinogenicity, and biological monitoring studies with epidemiology, it shows where necessary data, especially on exposed humans, are lacking for the evaluation of the health hazards of given exposures. Exposure monitoring provides a bridge between laboratory studies and studies of humans and can overcome some of the limitations of cancer epidemiology. Furthermore, the fact that data, obtained through the biological monitoring of biologically effective doses, and early (reversible) effects can be validated in parallel in laboratory animals and humans opens new avenues for improving human risk assessment. The incorporation of biological monitoring methods into conventional epidemiologic studies can increase their power to detect carcinogenic risk earlier, and at lower exposures, as well as to estimate more accurately the magnitude of human risk.

\section{Acknowledgments}

I wish to thank Ms M-J Ghess and Ms S Reynaud for their help in preparing this manuscript and Ms E Heseltine for her editorial assistance.

\section{References}

1. Autrup H, Bradeley KA, Shamsuddin AKM, Wakhisi J, Wasunna A. Detection of putative adduct with fluorescence characteristics identical to 2,3-dihydro-2(7'-guanyl)-3-hydroxyaflatoxin $\mathrm{B}_{1}$ in human urine collected in Murang'a district, Kenya. Carcinogenesis 4 (1983) 1193-1195.

2. Bartsch H, Ohshima H, Munoz N, Crespi M, Lu SH. Measurement of endogenous nitrosation in humans: Potential applications of a new method and initial results. In: Harris CC, Autrup H, ed. Human carcinogenesis. Academic Press, New York, NY 1983, pp $833-856$.

3. Berlin M, Tunek A. Benzene. In: Aitio A, Riihimäki V, Vainio $\mathrm{H}$, ed. Biological monitoring and surveillance of workers exposed to chemicals. Hemisphere Publishing Co, Washington, DC 1984, pp 67-81.

4. Braier L, Levy A, Dnor K, Pardo A. Benzene in blood and phenol in urine in monitoring benzene exposure in industry. Am J Ind Med 2 (1981) 119-123.

5. Brewen JG. Chromosome aberrations in mammals as genetic parameters in determining mutagenic potential and assessing genetic risk. In: Bora $\mathrm{KC}$, Douglas GR, Nestmann ER, ed. Chemical mutagenesis, human population monitoring and genetic risk assessment. Elsevier Biomedical Press, Amsterdam 1982, pp 261274.

6. Bridges BA. An approach to the assessment of the risk to man from DNA damaging agents. Arch Toxicol (1980): suppl 3, 271-281.

7. Cartwright RA, Glashan RW, Rogers HJ, Ahmad RA, Barham-Hall D, Higgins E, Kahn MA. Role of Nacetyltransferase phenotypes in bladder carcinogenesis: A pharmacogenetic epidemiological approach to bladder cancer. Lancet 2 (1982) 842-846.

8. Curtis RE, Hankey BF, Myers MH, Young JL Jr. Risk of leukemia associated with the first course of cancer treatment: An analysis of the Surveillance, Epidemiology and End Results program experience. J Natl Cancer Inst 72 (1984) $531-544$.

9. Ehrenberg L, Moustacchi E, Osterman-Golkar S. Dosimetry of genotoxic agents and dose-reponse relationships and their effects. Mutat Res 123 (1983) $121-$ 182.

10. Evans DAP, White TA. Human acetylation polymorphism. J Lab Clin Med 63 (1964) 394-403.

11. Falck K, Gröhn P, Sorsa H, Vainio H, Heinonen E, Holsti LR. Mutagenicity in urine of nurses handling cytostatic drugs. Lancet 1 (1979) 1250-1251.

12. Forni A. Chromosomal aberrations in monitoring exposure to mutagens-carcinogens. In: Berlin A, Draper $\mathrm{M}$, Hemminki K, Vainio $H$, ed. Monitoring human exposure to carcinogenic and mutagenic agents. International Agency for Research on Cancer, Lyon (in press). (IARC scientific publication no 59).

13. Hoffmann D, Brunnemann, KD. Endogenous formation of $\mathrm{N}$-nitrosoproline in cigarette smokers. Cancer Res 43 (1983) 5570-5574.

14. Högstedt B, Gullberg K, Hedner K, Koning AM, Mitelman F, Skerfving S. Widegren B. Chromosome aberations and micronuclei in bone marrow cells and peripheral blood lymphocytes in humans exposed to ethylene oxide. Hereditas 98 (1983) 105-113.

15. Hogstedt C, Aringer L, Gustavsson A. Ethylene oxide and cancer - Literature review and follow-up of two studies [in Swedish]. Arbetarskyddsverket, Stockholm (in press). (Arbete och hälsa).

16. International Agency for Research on Cancer. Some antineoplastic and immunosuppressive agents. Lyon 1981, pp 1-384. (IARC monographs on the evaluation of the carcinogenic risk of chemicals to humans, volume 26 ).

17. International Agency for Research on Cancer. Some 
aromatic amines, anthraquinones, nitroso compounds and inorganic fluorides-used in drinking water and dental preparations. Lyon 1982, pp 39-177. (IARC monographs on the evaluation of the carcinogenic risk of chemicals to humans, volume 27).

18. International Agency for Research on Cancer. Chemicals, industrial processes and industries associated with cancer in humans (IARC monographs, volumes 1 to 29). Lyon 1982, pp 31-34, 37-38, 166-167. (IARC monographs on the evaluation of the carcinogenic risk of chemicals to humans, supplement 4).

19. International Agency for Research on Cancer. Some industrial chemicals and dyestuffs. Lyon 1982, pp 93148. (IARC monographs on the evaluation of the carcinogenic risk of chemicals to humans, volume 29).

20. International Agency for Research on Cancer. Polynuclear aromatic compounds: Part 1. Chemical, environmental and experimental data. Lyon 1983, pp 3391. (IARC monographs on the evaluation of the carcinogenic risk of chemicals to humans, volume 32).

21. International Agency for Research on Cancer. IARC internal technical report: Monitoring of aflatoxins in human body fluids and application to field studies: Report of a working group. Lyon 1984, pp 1-26.

22. International Agency for Research on Cancer. Some allyl and allylic compounds, aldehydes, epoxides and peroxides. Lyon (in press). (IARC monographs on the evaluation of the carcinogenic risk of chemicals to humans, volume 36 ).

23. Laires A, Borba H, Rueff J, Gomes MI, Halpern M. Urinary mutagenicity in occupational exposure to mineral oils and iron oxide particles. Carcinogenesis 3 (1982) $1077-1079$.

24. Lambert B, Lindblad A, Holmberg K, Francesconi D. Use of sister chromatid exchange to monitor human populations for exposure to toxicologically harmful agents. In: Wolff S, ed. Sister chromatid exchange. John Wiley \& Sons, New York, NY 1982, pp 149-182.

25. Lauwerys RL. Industrial chemical exposure: Guidelines for biological monitoring. Biomedical Publications, Davis, CA 1983, pp 1-150.

26. Lower GM Jr, Nilsson T, Nelson CE, Wolf H, Gamsky TE, Byran GT. N-Acetyltransferase phenotype and risk in urinary bladder cancer: Approaches in molecular epidemiology: Preliminary results in Sweden and Denmark. Environ Health Perspect 29 (1979) 71-79.

27. Maltoni C, Conti B, Cotti G. Benzene: A multipotential carcinogen: Results of long-term bioassays performed at the Bologna Institute of Oncology. Am J Ind Med 4 (1983) 589-630.

28. Mason WS, Halpern MS, Thomas W. Hepatitis B viruses, liver disease and hepatocellular carcinoma. Cancer Surv 3 (1984) 1.

29. Meyne J, Legator MS. Sex-related differences in cytogenetic effects of benzene in the bone marrow of Swiss mice. Environ Mutagenesis 2 (1980) 43-50.

30. Nikula E, Kiviniitty K, Leisti J, Taskinen PJ. Chromosome aberrations in lymphocytes of nurses handling cytostatic agents. Scand J Work Environ Health 10 (1984) $71-74$.

31. Norppa H, Sorsa M, Vainio H, Gröhn E, Heinonen E, Holsti L, Nordman E. Increased sister chromatid exchange frequencies in lymphocytes of nurses handling cytostatic drugs. Scand J Work Environ Health 6 (1980) 229-301.

32. Ohshima H, Bartsch H. Monitoring endogenous nitrosamine formation in man. In: Berlin A, Draper $\mathbf{M}$, Hemminki K, Vainio $H$, ed. Monitoring human ex- posure to carcinogenic and mutagenic agents. International Agency for Research on Cancer, Lyon (in press). (IARC scientific publications no 59).

33. Perera FP, Poirier MC, Yuspa SH, Nakayama J, Jaretzki A, Curren MM, Knowles DM, Weinstein IB. A pilot project in molecular cancer epidemiology: Determination of benzo(a)pyrene-DNA adducts in animal and human tissues by immunoassays. Carcinogenesis 3 (1982) 1405-1410.

34. Perera FP, Weinstein IB. Molecular epidemiology and carcinogen-DNA adduct detection: New approaches to studies of human cancer causation. J Chronic Dis 35 (1982) $581-600$.

35. Randerath K, Reddy MV, Gupta RC. ${ }^{32}$ P-labeling test for DNA damage. Proc Natl Acad Sci USA 78 (1981) $6126-6129$

36. Segerbäck D. Alkylation of DNA and hemoglobin in the mouse following exposure to ethene and ethene oxide. Chem Biol Interactions 45 (1983) 139-151.

37. Shamsuddin AKM, Sinopoli NT, Vahakangas K, Hemminki K, Boesch RR, Harris CC. Identification of benzo(a)pyrene diol epoxide-DNA antigenicity in humans. Fed Proc 42 (1983) 1042.

38. Skipper PL, Bryant MS, Tannenbaum SR, Groopman JD. Analytical methods for assessing exposure to 4aminobiphenyl based on protein adduct formation. In: Conference on medical screening and biological monitoring for the effects of exposure in the workplace. July 10-13 1984, Cincinnati, Ohio, Abstracts. 1984, p 58.

39. Skipper PL, Green LC, Bryant MS, Tannenbaum SR. Monitoring exposure to 4-aminobiphenyl via blood protein adducts. In: Berlin A, Draper M, Hemminki $\mathrm{K}$, Vainio $\mathrm{H}$, ed. Monitoring human exposure to carcinogenic and mutagenic agents. International Agency for Research on Cancer, Lyon (in press). (IARC scientific publication no 59).

40. Snellings WM, Weil CS, Maronpot RR. A two-year inhalation study of the carcinogenic potential of ethylene oxide in Fischer 344 rats. Toxicol Appl Pharmacol 75 (1984) 105-117.

41. Sorsa $M$, Norppa $H$, Vainio $H$. Induction of sister chromatid exchanges among nurses handling cytostatic drugs. In: Bridges BA, Butterworth BE, Weintein IB, ed. Indicators of genetoxic exposure. Cold Spring Harbor Laboratory, Cold Spring Harbor, NY 1982, pp 341-350. (Banbury report no 13).

42. Stolley PD, Soper KA, Galloway SM, Nichols WW, Norman SA, Wolman SR. Sister chromatic exchanges in association with occupational exposure to ethylene oxide. Mutat Res (in press).

43. Vainio H, Sorsa M. Application of short-term tests in monitoring occupational exposure to complex mixture. In: Waters MD, Sandhu SS, Lewtas J, Claxton L, Chernoff N, Nesnow S, ed. Short-term bioassays in the analysis of complex environmental mixtures: Part IV. Plenum Press, New York, NY (in press).

44. Waksvik H, Klepp O, Brogger O. Chromosomes analyses of nurses handling cytostatic agents. Cancer Treat Rep 65 (1981) 607-610.

45. Wright AS. Molecular dosimetry techniques in human risk assessment: An industrial perspective. In: Mages AW, Schnell RC, Miya TS, ed. Developments in the science and practice of toxicology. ICT, Elsevier Biomedical Press, Amsterdam 1983, pp 311-318.

Received for publication: 12 November 1984 